\title{
Teachers' Perspective on Scientific Literacy in Science Learning: Descriptive Survey
}

\author{
Indra Budiman ${ }^{1 *}$, Ida Kaniawati ${ }^{1}$, Anna Permanasari ${ }^{1}$, Iwa Lukmana ${ }^{1}$ \\ ${ }^{1}$ Science Education, Universitas Pendidikan Indonesia, Bandung, Indonesia
}

DOI: $10.29303 /$ ippipa.v7iSpecialIssue.1123

\section{Article Info}

Received: November $11^{\text {th }}, 2021$

Revised: December 6 $6^{\text {th }}, 2021$

Accepted: December 8th, 2021

\begin{abstract}
Survey of questionnaire-based research was conducted to assess the perspective of junior high school (JHS) science teachers on scientific literacy in science learning. Four perspectives for teachers in JHS on scientific literacy were obtained from the research results of the experiments, namely the reading of scientific texts, scientific knowledge, the use of science in everyday life and the use of science-based learning tools. The majority of participants chose the response choice to train all students to apply science learning results in decision-making on daily life challenges. Thus, JHS Science Teachers in Purwakata Regency have a variety of scientific literacy perspectives, but there is no perspective that is considered outside the context of scientific literacy.
\end{abstract}

Keywords: Science teacher; scientific literacy; science learning.

Citation: Budiman, I., Kaniawati, I., Permanasari, A., \& Lukmana, I. (2021). Teachers' Perspective on Scientific Literacy in Science Learning: Descriptive Survey. Jurnal Penelitian Pendidikan IPA, 7(Speciallssue), 218-224. https://doi.org/10.29303/jppipa.v7iSpeciallssue.1123

\section{Introduction}

There is no single accepted definition of scientific literacy; instead, the many characteristics of scientific literacy discussed in the literature include various components of scientific inquiry skills, knowledge of content, and attitudes towards science (Fives, et al., 2014). Definitions of scientific literacy are growing because more understanding the nature of science (NOS) and 21st-century citizenship (Feinstein, 2011). Norris \& Phillips, (2003) have stated that the reconstruction of scientific literacy more than scientifically literate can read, write and share science texts. Scientific literacy has been expanded to include more than just asking students to know the content of the sciences (Norris \& Phillips, 2003). Instead, students are asked to apply their scientific knowledge by critically interpreting information using reasonable evidence, taking scientific decisions with evidence, and managing their uncertainty and negotiating ideas with claims to conflict (Clark \& Lott, 2017; Kersten, 2017; Nam \& Chen, 2017).
A wide range of worldwide policy documents (e.g., Commission, 2000; OECD, 2011) recognized the important cancellation of the broader goal of scientific literacy for all secondary school learners. Curriculum reform attempts have focused on science learning as an objective not only for scientist education but for the general public as well. The primary hypothesis of these efforts is that in industrialized and democratic societies, as part of active citizenship, the public needs to be better equipped with science reasoning capabilities to make informed choices on multiple issues ranging from climate change to genetic cloning. The inclusion of subjects such as NOS and the understanding of science in its socio-cultural context is a particular component of the push for "scientific literacy for all." Among the numerous factors proposed as to why scientific literacy is significant (e.g. Pahrudin, et al., 2019; DeBoer, 2000), the capacity of lay people to engage with science that affects their daily life is essential.

The Program survey for the International Student Assessment (PISA) survey in 2006, which specifically focused on the study on science, showed that Indonesian students' literacy skills were still at a

\footnotetext{
*Email: indra.budiman@upi.edu
} 
low level, namely $29 \%$ for content, $34 \%$ for the process, and $32 \%$ for context. A decade later, in 2016, PISA reported that Indonesia was still ranked 64th out of 72 participating countries with a score of 403 , while the average score was 493 . From the findings, especially in the context of the application of science, it is evident that many students in Indonesia cannot associate the knowledge of science they learn with the phenomena found in everyday life. The data shows that the learning objectives of science in Indonesia have not been satisfactory (OECD, 2006; OECD, 2015).

Science education has a vital role to play in preparing a scientifically literate citizenry capable of understanding the complicated environmental problems facing human societies and making wellinformed and evidence-based choices that assist solve these problems (Sharma \& Buxton, 2015). Many factors in the scientific literacy of students in Indonesia for a decade are still low compared to other countries, one of which is the teacher's factor. Some previous studies stated that suitable curriculum materials can enhance student knowledge of science and are connected to changes that educators make in the culture of the classroom, facilitated by increased curriculum materials (Debarger, et al., 2016). Science teachers need to develop a specific "PCK for nature of science," an alternative, more comprehensive notion of PCK (Pedagogical Content Knowledge) for science teaching is suggested (Van Dijk, 2014). Barnes research results that knowledge of the nature of science is a critical component in scientific literacy for secondary school students (Barnes, et al., 2015). Teachers who teach science express opinions about teaching into three groups of themes, namely 1) A Changing World, My Beliefs, and Tried and True. Teachers with the A Changing World epistemology believe the evidence is reliable, and scientific knowledge is generated in multiple ways and science changes in light of new evidence. The My Beliefs epistemology reflects that scientific knowledge is subject to change due to embedded bias. Science is affected by culture and religion, and evolution should not be taught in the classroom. The Tried-and-True epistemology views a scientific method as an exact method to prove science, believes experiments are crucial for scientific discoveries, absolute truth exists in scientific knowledge, and social and cultural factors can be eliminated from investigations.

Many previous studies have focused on the scientific literacy skills of teachers, such as the results of Rubini's study reported that $20 \%$ of teachers have lowcategory science literacy skills, moderate-category $65 \%$ and high-category 15\% (Rubini et al., 2016). The standard science curriculum is intended to familiarize learners in biology, chemistry, and physics with fundamental ideas. Students, particularly those interested in biology, may be tempted to correlate science potential with the capacity for an examination to maintain and recall data (Nath, et al., 2015). Importance has been given to promoting educators to participate in scientific critical written and oral discourse activities that support the SWH strategy and are vital characteristics of scientific literacy (Hand, et al., 2018). The pre-service science educators are usually positive about the notion of science and technology, and the perception is consistent with the literature, so educators are showing that they are learning about science and technology (Ekici \& Aydoğdu, 2014). Not only do learners experience the issue of low scientific literacy, but the professors of science, which is a significant element of the teaching process, are still not satisfactory (Rubini, et al., 2017).

The difference between this research and previous studies is the difference in focus and methodology used. Based on the context of previous research, the focus of this research is the perspective of Middle School Science Teachers on scientific literacy in science learning. The purpose of this study was to investigate the perceptions of junior high school science teachers on scientific literacy in science learning. The results of this study can be used as recommendations for the continuous professional development activities of junior high school science teachers about the knowledge and application of science literacy in learning in science class.

\section{Method}

This study uses a qualitative approach with a survey method. The descriptive analysis focused on the participants' answers. The participants in this study were junior high school science teachers in Purwakarta Regency, West Java Province. All participants usually hold meetings in the Teacher Science Forum (MGMP Purwakarta District). This study is estimated to be 16 weeks until all required data is collected.

Based on data from the website of the Ministry of Education and Culture of the Republic of Indonesia (http://niep.data. kemdikbud.go.id) in the Purwakarta Regency area, there are 113 junior high schools or equivalent with 132 total science teachers. In this study, 96 science teachers were willing to become participants. Of the total 96 participants, the number of female participants was almost three times the number of male participants. The following are the profile of participants reviewed by sex, age category, formal education background, professional training ever attended, teaching experience and workload per week in the science subject. 
Table 1. Participant Profile

\begin{tabular}{|c|c|c|c|c|c|}
\hline Gender & Age & Formal Education & $\begin{array}{l}\text { Professional } \\
\text { Training }\end{array}$ & $\begin{array}{l}\text { Teaching } \\
\text { Experience }\end{array}$ & $\begin{array}{l}\text { Workload Classes } \\
\text { per Week }\end{array}$ \\
\hline & $\begin{array}{l}30-39 \text { Years Old }= \\
36.50 \% \\
40-49 \text { Years Old }= \\
28.10 \% \\
50-60 \text { Years Old }= \\
12.50 \%\end{array}$ & $\begin{array}{l}\text { Chemistry Education } \\
=3.10 \% \\
\text { Science Education = } \\
4.20 \% \\
\text { Physisc }=0 \% \\
\text { Biology }=8.30 \% \\
\text { Chemistry }=2.10 \% \\
\text { Others }=25 \%\end{array}$ & & $\begin{array}{l}11-15 \text { Years= } \\
20.80 \% \\
16-20 \text { Years } \\
=16.70 \% \\
\text { Up to } 20 \text { Years }= \\
16.70 \%\end{array}$ & $>31=0 \%$ \\
\hline
\end{tabular}

The data collection technique used in this study was using a questionnaire. Some questions in this questionnaire were adapted from the research results by Sarkar \& Corrigan, (2013). This questionnaire is structured into three parts: alternative response type questions, rating type questions, and open-ended questions. The questionnaire was made in the form of Google Form to facilitate data collection, especially data accuracy, and reduce paper use (Rasdiana, et al., 2016).

Analysis of the data used in this research is inductive thematic analysis. The goal is to identify patterns or find themes through data (Braun \& Clarke, 2006). This thematic analysis method is very effective for finding the patterns of phenomena and how they occur (Fereday \& Muir-Cochrane, 2006). There are three stages of thematic data analysis, namely: 1) Understanding data, 2) Arranging code, and 3) Finding themes (Heriyanto, 2018). For data that has been collected through a questionnaire, open-ended type questions in the form of scientific literacy concept data written by the teachers were analyzed thematically, grouped according to the theme. Data through questionnaires alternative response type questions, each response is calculated based on alternative answers and then made a percentage. In contrast, data is taken through instruments rating type questions, grouped into four attitude scales: always, often, sometimes and rarely, with scores in sequence 4, 3, 2, and 1.

\section{Result and Discussion}

Data from the results of this study include participant opinion data about the objectives of science learning, data on participant perceptions of scientific literacy, and participant attitude data as data for the triangulation process. Based on closed questionnaire questions about the purpose of science learning in junior high schools, participants were given two choices that reflected the two science learning objectives-Table 2 about participants' opinions about the purpose of science learning in junior high school.

Table 2. Science Learning Objectives in Junior High School School According to Participants

\begin{tabular}{llll}
\hline No & Learning objectives & Frequency & Percentage (\%) \\
\hline 1 & Make all students able to apply science learning outcomes in everyday life & 66 & 68.80 \\
\hline 2 & $\begin{array}{l}\text { Building the basics of scientific knowledge as a provision for students in advanced } \\
\text { studies at a higher level }\end{array}$ & 30 & 31.20 \\
\hline
\end{tabular}

Most participants $(68.80 \%)$ chose the answer option 'making all students able to apply science learning outcomes in everyday life. In comparison, some participants $(31.20 \%)$ chose the answer option 'building the basics of scientific knowledge as a provision for students in further studies at a higher level'. Most participants perceive that learning science needs not only knowledge of content but also knowledge of procedures and epistemic knowledge (Kind \& Osborne, 2016). One of the school activities that become the miniature of applying science learning outcomes in everyday life can be through science fair projects. Students can experience the process of developing and completing a student-driven investigation for a science fair that engages students in the scientific practices envisioned by curriculum document (Koomen, et al., 2018). So teachers are expected to adopt the curriculum-where current curriculum materials are specifically modified-can provide a significant strategy for teacher leaders in schools and districts to promote improvements in classroom practice in line with the framework vision 
(Debarger, et al., 2016). The curriculum allowed students to move beyond academic achievement to position themselves as transformative thinkers. As transformative intellectuals, students proved complicated thinking about problems related to science and social justice, cultivated their dedication to their original societies and cultures, and established credibility as knowledgeable local youth in science. So Teachers can engage with science education as a catalyst for social transformation (Morales-Doyle, 2017).

To understand the concept of scientific literacy, participants filled out an open questionnaire to describe their conceptions of scientific literacy in their own words. The themes that emerge from participant written responses are presented in Table 3, along with their frequency and percentage.

Table 3. Themes of the Concept of Science Literacy According to Participants

\begin{tabular}{llll}
\hline No & Themes & Frequency & Percentage (\%) \\
\hline 1 & $\begin{array}{l}\text { Read text related to science } \\
2\end{array}$ & $\begin{array}{l}\text { Have an understanding of } \\
\text { science }\end{array}$ & 25 \\
3 & $\begin{array}{l}\text { The use of science in } \\
\text { everyday life }\end{array}$ & 45 & 26.00 \\
4 & Source of science learning & 11 & 46.90 \\
\hline
\end{tabular}

Table 4 shows the data on the attitudes of science learning participants derived from the results of the attitude scale instrument used as a comparison in the triangulation process.

Table 4. Attitudes of Participants to Science Learning

\begin{tabular}{lll}
\hline No & Aspects of Teaching Practice & Average Score \\
\hline 1 & Teachers teach science material associated with examples in students' daily lives. & 3.41 \\
2 & Teachers explain science applications in everyday life. & 3.20 \\
3 & $\begin{array}{l}\text { The teacher encourages students to be involved in class discussions about the experience of applying } \\
\text { science material in life. }\end{array}$ & 3.01 \\
4 & $\begin{array}{l}\text { The teacher encourages students to learn science from various learning resources, including } \\
\text { newspapers, magazines, TV, enrichment books, radio, internet, etc. }\end{array}$ & 3.19 \\
& The teacher exemplifies science based on students' interests and talents. & 2.68 \\
\hline
\end{tabular}

Based on Table 3, four major themes arise from participant responses as perceptions of scientific literacy. The theme of 'the use of science in everyday life' appears as the most frequent, namely 45 times or $46.90 \%$. Examples of written responses to this theme are as follows: Scientific literacy is the application of children to understand the scope of natural science by exploring from various sources and can be applied in daily life (Teacher No. 89). Another example, in my opinion, scientific literacy is the ability of students to apply learning outcomes to problems that occur and draw conclusions from the evidence. This is done so that students better understand and can make decisions and changes that occur in nature through human activities (Teacher No. 82). Scientific literacy is a way to understand science and to apply and apply it to the benefit of society (Teacher No. 3).

From the participant responses about scientific literacy, almost half stated that scientific literacy is the use of science in everyday life. This is following the choice of the goal of the teacher's science learning, which is more than half of $68.80 \%$, stating that science learning in junior high school is a learning process so students can apply science learning outcomes in their daily lives. Participant's perceptions were reinforced by his attitude towards science learning, with an average of 3.41 participants almost always teaching science material associated with examples in students' daily lives (note Table 4). Participants' perceptions of scientific literacy are in line with the results of research by In the development of scientific literacy, it is prioritized to reform the school curriculum in terms of teaching science issues related to the interests and daily lives of students (Schulte, 2014).

The theme of the concept of scientific literacy from participants' responses "having a scientific understanding" has a frequency of 25 or $26 \%$. This theme has the second-highest frequency. The following is an example of a participant's written response to scientific literacy: Scientific ability in order to understand the Universe (Teacher No. 8). Science literacy, in my opinion, is the capital to build a good future useful and useful for future life (Teacher No. 15). Science literacy, in my opinion, is able to understand, read, understand and explore more about science and matters relating to science (Teacher No. 30 ).

The responses to the theme are related to the answer choices in science learning goals, namely 'building the basics of scientific knowledge as a provision for students in advanced studies at a higher level'. They assume that scientific literacy is the ability to understand science. The ability to grasp science is the capital to continue education to a higher level or become capital to be used in daily life; in other words, the results of science learning are not necessarily implemented in daily life but must be understood first. 
This is reinforced by the attitude of participants to science learning that often explains the application of science in everyday life (Table 4). The exciting thing is the response of Teacher No. 15. In response, the teacher emphasizes morality or values. This agrees with Chowdhury (2016) that with the rapid advancement of science and technology, the increasingly complex social change of society requires teachers who teach ethics, morals, values, character to their students in facing future challenges. Because moral is an abstract thing for students, the teacher must identify implicit metaphors in students' science language; they will better understand students' ideas (Daane, et al., 2018).

Regarding teacher responses with the theme 'having a scientific understanding', there are some teachers who respond that scientific literacy is an activity of reading books related to science. The theme groups of participants' responses, "reading texts related to science", have a frequency of 15 or $15.60 \%$. Participants in this theme think that understanding science must first read books related to science. The following is an example of participants' responses to scientific literacy, which is perceived as an activity of reading books related to science: I think science literacy is reading science-related knowledge books. (Teacher No. 92). Another example, science literacy is reading science from textbooks or the surrounding world. (Teacher No. 83). This participant's perception is reinforced by his attitude, which often encourages students to learn science from various learning sources, including newspapers, magazines, TV, enrichment books, radio, internet, etc. (Table 4). This participant's perception can be implemented by reading various genres of text relating to science because the variety of text genres in science classrooms reveal opportunities to use them in hands-on, minds-on science (Faller, 2017). So scientific teachers should be encouraged to include scientific literature in reading activities in the classroom. Scientific literature generates epistemological reading results that are more useful than popular scientific literature and scientific literature (Braun \& Nückles, 2014).

The fourth theme of the last participant written responses, namely 'science learning sources', has a frequency of 11 or $11.50 \%$. Following is an example of participant responses. Science literacy is as a resource person, benchmarking guide, or as a reference (Teacher No. 1). Science literacy is the use of various media such as books, environment, technology and others as a source of learning science education (Teacher No. 63). Science literacy is all knowledge information about science that is obtained by students from all learning resources, both in the form of text, practical activities, derived from teachers, books, information media networks both in schools and the environment (Teacher No. 69).

From these responses, the teacher considers science literacy to be a source of learning science. This is related to the previous theme; namely, scientific literacy is a reading activity. Reading resources can be in the form of textbooks, practical exercises, the internet, and the surrounding environment. This participant's perception is related to his attitude towards science learning, which sometimes participants exemplify science based on students' interests and talents (Table 4). One way to implement it is that teachers can use learning resources such as journalistic science activities in schools because this can allow students to assist better them make a meaningful contribution to government discourse long after graduation from high school (Polman, et al., 2014).

This survey was put in place for all science teachers at the junior high school level in Purwakarta Regency, West Java. But from data obtained there are $25 \%$ of participants do not have a formal educational background, both from science, physics, biological and chemical education. This means that they have educational backgrounds for all kinds of study fields. This needs a profound survey about the competence of science literacy for those with non-science education, physics, biology and chemical.

\section{Conclusion}

Junior High School science teachers in Purwakarta Regency have various scientific literacy perspectives. No perspective is considered out of the context of scientific literacy. This is because it is supported by the educational background that has fulfilled the undergraduate qualifications, and there are even some teachers who have mastered Masters/S2 qualifications. Regarding the learning practices, the junior high school science teacher emphasizes to students the mastery of science material while applying it to everyday life. This is supported by teaching experience, which is above five years on average, and almost all have attended professional training (82.30\%). The perception of the Purwakarta Middle School Science teacher on scientific literacy is by the implementation of learning in the classroom. So what becomes a conception of scientific literacy is manifested in the teaching and learning process. Although the perception of the Purwakarta Middle School Science teacher on scientific literacy and learning practices is not out of context, the results of the PISA test, Indonesian students are still at the bottom, so it should be necessary to strengthen knowledge and practice of teaching science literacy for teachers to improve students' scientific literacy competencies. This survey 
also needs to be re-engineered to further explore science teachers' competence with non-education, physics, biological and chemical.

\section{Acknowledgments}

The author thanks the teacher and students at SMP Negeri, West Java, and Mr Elih Sutisna Yanto for his suggestions while making this manuscript.

\section{References}

Barnes, C., Angle, J., \& Montgomery, D. (2015). Teachers Describe Epistemologies of Science Instruction Through Q Methodology. School Science and Mathematics, 115(3), 141-150. https://doi.org/10.1111/ssm.12111.

Braun, I., \& Nückles, M. (2014). Scholarly Holds Lead Over Popular and Instructional: Text Type Influences Epistemological Reading Outcomes. Science Education, 98(5), 867-904. https://doi.org/10.1002/sce.21117.

Braun, V., \& Clarke, V. (2006). Using Thematic Analysis in Psychology. Qualitative Research in Psychology, 3(2),77-101.

https:// doi.org/10.1191/1478088706qp063oa.

Chowdhury, M. (2016). Emphasizing Morals, Values, Ethics, and Character Education in Science Education And Science Teaching. The Malaysian Online Journal of Educational Science, 4- 2. Retrieved

from. https://eric.ed.gov/?id=EJ1095995

Clark, S. K., \& Lott, K. (2017). Integrating science inquiry and literacy instruction for young children. The Reading Teacher, 70(6), 701-710. https://doi.org/10.1002/t

Commission, E. (2000). Learning for life, learning through life: Reform proposals for the 780 education system in Hong Kong. Education Commission.

Daane, A. R., Haglund, J., Robertson, A. D., Close, H. G., \& Scherr, R. E. (2018). The pedagogical value of conceptual metaphor for secondary science teachers. Science Education, 102(5), 1051-1076. https://doi.org/10.1002/sce.21451.

Debarger, A. H., Penuel, W. R., Moorthy, S., Beauvineau, Y., Kennedy, C. A., \& Boscardin, C. K. (2016). Investigating Purposeful Science Curriculum Adaptation as a Strategy to Improve Teaching and Learning. Science Education, 101(1), 66-98. https://doi.org/10.1002/sce.21249.

Ekici, F. T., \& Aydoğdu, M. (2014). Perceptions of Prospective Science Teachers about Science and Technology Concepts and ScientificTechnological Literacy. International Research in
Education,

2(1),

169.

https://doi.org/10.5296/Ire.V2i1.4965

Faller, S. E. (2017). Reading and Writing as Scientists? Text Genres and Literacy Practices in Girls. Middle-Grade Science. Journal of Adolescent \& Adult Literacy, 61(4), 381-390. https://doi.org/10.1002/jaal.698.

Feinstein, N. (2011). Salvaging science literacy. Science Education, 95(1), 168-185. https://doi.org/10.1002/sce.20414.

Fereday, J., \& Muir-Cochrane, E. (2006). Demonstrating Rigor Using Thematic Analysis: A Hybrid Approach of Inductive and Deductive Coding and Theme Development. International Journal of Qualitative Methods, 5(1), 80-92. https://doi.org/10.1177/160940690600500107.

Fives, H., Huebner, W., Birnbaum, A. S., \& Nicolich, M. (2014). Developing a Measure of Scientific Literacy for Middle School Students. Science Education, 98(4), 549-580. https://doi.org/10.1002/sce.21115.

Hand, B., Park, S., \& Suh, J. K. (2018). Examining Teachers' Shifting Epistemic Orientations in Improving Students' Scientific Literacy through Adoption of The Science Writing Heuristic Approach. Global Developments in Literacy Research for Science Education, 339-355. https://doi.org/10.1007/978-3-319-69197-8_20

Heriyanto, H. (2018). Thematic Analysis sebagai Metode Menganalisa Data untuk Penelitian Kualitatif. Anuva, 2(3), 317. https://doi.org/10.14710/anuva.2.3.317-324 [Indonesian]

Kersten, S. (2017). Becoming nonfiction authors: Engaging in science inquiry. The Reading Teacher, 71(1), 33-41. https://doi.org/10.1002/trtr.1577.

Kind, P., \& Osborne, J. (2016). Styles of Scientific Reasoning: A Cultural Rationale for Science Education? Science Education, 101(1), 8-31. https://doi.org/10.1002/sce.21251.

Koomen, M. H., Rodriguez, E., Hoffman, A., Petersen, C., \& Oberhauser, K. (2018). Authentic science with citizen science and student-driven science fair projects. Science Education, 102(3), 593-644. https://doi.org/10.1002/sce.21335.

Morales-Doyle, D. (2017). Justice-centered science pedagogy: A catalyst for academic achievement and social transformation. Science Education, 101(6), 1034-1060. https://doi.org/10.1002/sce.21305.

Nam, Y., \& Chen, Y. C. (2017). Promoting argumentative practice in socio-scientific issues through a science inquiry activity. EURASIA Journal of Mathematics, Science and Technology 
Education,

13(7)

3431-3461. https://doi.org/10.12973/eurasia.2017.00737a

Nath, S., Tang, B., \& Yang, K. (2015). Enhancing Scientific Literacy: A Resource for Teachers. Journal of Student Science and Technology, 8(1). https://doi.org/10.13034/jsst.v8i1.51

Norris, S. P., \& Phillips, L. M. (2003). How literacy in its fundamental sense is central to scientific literacy. Science Education, 87(2), 224-240. https://doi.org/10.10.

OECD. (2006). PISA 2006: Science Competencies for Tomorrow's World. (Vol. 1). OECD Publishing.

OECD. (2011). Education at a glance 2011: OECD indicators. OECD Publishing. https://doi.org/10.1787/eag-2011-en

OECD. (2015). Pisa 2015 Results in Focus. OECD Publishing.

Polman, J. L., Newman, A., Saul, E. W., \& Farrar, C. (2014). Adapting Practices of Science Journalism to Foster Science Literacy. Science Education, 98(5),

766-791. https://doi.org/10.1002/sce.21114.

Rasdiana, E., Muhamad, F. N., \& Kurniaji, R. (2016). Pemanfaatan Rinfo Form Sebagai Media Pembuatan Kuesioner Dalam Proses Pengumpulan Data Pada Perguruan Tinggi. Technomedia Journal, 1(1), 78-94. https://doi.org/10.33050/tmj.v1i1.21 [Indonesian]

Rubini, B., Ardianto, D., Pursitasari, I. D., \& Hidayat, A. (2016). Identify Scientific Literacy from the Science Teachers' Perspective. Jurnal Pendidikan IPA Indonesia, 5(2), 299-303. https://doi.org/10.15294/Jpii.V5i2.7689.

Rubini, B., Ardianto, D., Pursitasari, I. D., \& Permana, I. (2017). Professional Development Model for Science Teachers Based On Scientific Literacy. IOP Conference Series: Materials Science and Engineering, 166, 12037. https://doi.org/10.1088/1757899x/166/1/012037.

Sarkar, M., \& Corrigan, D. (2013). Bangladeshi Science Teachers' Perspectives of Scientific Literacy And Teaching Practices. International Journal of Science and Mathematics Education, 12(5), 1117-1141. https://doi.org/10.1007/s10763-013-9450-8.

Schulte, T. (2014). Students' And Teachers' Perceptions Of School-Based Scientific Literacy Priorities And Practice: A Cross-Cultural Comparison Between Cyprus And Germany. Conference Paper. https://www.researchgate.net/publication/264 422162.

Sharma, A., \& Buxton, C. A. (2015). Human-Nature Relationships in School Science: A Critical Discourse Analysis of a Middle-Grade Science
Textbook. Science Education, 99(2), 260-281. https://doi.org/10.1002/sce.21147

Van Dijk, E. M. (2014). Understanding the Heterogeneous Nature of Science: A Comprehensive Notion of PCK for Scientific Literacy. Science Education, 98(3), 397-411. https://doi.org/10.1002/sce.21110 